\title{
Peroxynitrite-mediated oxidation of ferrous carbonylated myoglobin is limited by carbon monoxide dissociation
}

\author{
Paolo Ascenzi ${ }^{\text {a,b,* }}$, Chiara Ciaccio ${ }^{\mathrm{c}, \mathrm{d}}$, Massimo Coletta ${ }^{\mathrm{c}, \mathrm{d}}$ \\ a Department of Biology and Interdepartmental Laboratory for Electron Microscopy, University 'Roma Tre', \\ Viale Guglielmo Marconi 446, I-00146 Roma, Italy \\ b National Institute for Infectious Diseases I.R.C.C.S. 'Lazzaro Spallanzani', Via Portuense 292, I-00149 Roma, Italy \\ ${ }^{\mathrm{c}}$ Department of Experimental Medicine and Biochemical Sciences, University of Roma 'Tor Vergata', Via Montpellier 1, I-00133 Roma, Italy \\ ${ }^{\mathrm{d}}$ Interuniversity Consortium for the Research on the Chemistry of Metals in Biological Systems (CIRCMSB), Piazza Umberto I 1, I-87100 Bari, Italy
}

Received 12 September 2007

Available online 24 September 2007

\begin{abstract}
Peroxynitrite-mediated oxidation of ferrous nitrosylated myoglobin $(\mathrm{Mb}(\mathrm{II})-\mathrm{NO})$ involves the transient ferric nitrosylated species $(\mathrm{Mb}(\mathrm{III})-\mathrm{NO})$, followed by $\cdot \mathrm{NO}$ dissociation and formation of ferric myoglobin $(\mathrm{Mb}(\mathrm{III}))$. In contrast, peroxynitrite-mediated oxidation of ferrous oxygenated myoglobin $\left(\mathrm{Mb}(\mathrm{II})-\mathrm{O}_{2}\right)$ involves the transient ferrous deoxygenated and ferryl derivatives ( $\mathrm{Mb}$ (II) and $\mathrm{Mb}(\mathrm{IV})=\mathrm{O}$, respectively), followed by $\mathrm{Mb}(\mathrm{III})$ formation. Here, kinetics of peroxynitrite-mediated oxidation of ferrous carbonylated horse heart myoglobin $(\mathrm{Mb}(\mathrm{II})-\mathrm{CO})$ is reported. Values of the first-order rate constant for peroxynitrite-mediated oxidation of $\mathrm{Mb}(\mathrm{II})-\mathrm{CO}$ (i.e., for $\mathrm{Mb}(\mathrm{III})$ formation) and of the first-order rate constant for $\mathrm{CO}$ dissociation from $\mathrm{Mb}$ (II)- $\mathrm{CO}$ (i.e., for $\mathrm{Mb}$ (II) formation) are $h=(1.2 \pm 0.2) \times 10^{-2} \mathrm{~s}^{-1}$ and $k_{\mathrm{off}(\mathrm{CO})}=(1.4 \pm 0.2) \times 10^{-2} \mathrm{~s}^{-1}$, respectively, at $\mathrm{pH} 7.2$ and $20.0^{\circ} \mathrm{C}$. The coincidence of values of $h$ and $k_{\text {off( }(\mathrm{CO})}$ indicates that $\mathrm{CO}$ dissociation represents the rate limiting step of peroxynitrite-mediated oxidation of $\mathrm{Mb}(\mathrm{II})-\mathrm{CO}$.

(c) 2007 Elsevier Inc. All rights reserved.
\end{abstract}

Keywords: Ferrous carbonylated horse heart myoglobin; Peroxynitrite; Peroxynitrite-mediated oxidation; Kinetics

Carbon monoxide $(\mathrm{CO})$, dioxygen $\left(\mathrm{O}_{2}\right)$, and nitrogen monoxide ( $\left.{ }^{\mathrm{NO}}\right)$ are pivotal for life, being (co)substrates, products, and/or modulators in many enzymatic processes such as oxidative respiration, denitrification, carbon and nitrogen fixation, and methanogenesis (see [1-4]).

$\mathrm{CO}, \mathrm{O}_{2}$, and $\mathrm{NO}$ bind to metal centers, e.g. to the sixth coordination position of ferrous heme-proteins (heme$\mathrm{Fe}(\mathrm{II})$-proteins). $\mathrm{NO}$ also reacts with ferric $\mathrm{Fe}$ centers (e.g., the ferric heme-Fe-atom (Fe(III)) (see [5-12]). Note that $\mathrm{NO}$ and $\mathrm{CO}$ induce heme-Fe(III)-atom reduction (see [13-18]); in contrast, $\mathrm{O}_{2}$ facilitates heme-Fe(II)-atom

\footnotetext{
Abbreviation: $\mathrm{Mb}$, myoglobin.

* Corresponding author. Address: Department of Biology and Interdepartmental Laboratory for Electron Microscopy, University 'Roma Tre', Viale Guglielmo Marconi 446, I-00146 Roma, Italy. Fax: +39 065517 6321.

E-mail address: ascenzi@bio.uniroma3.it (P. Ascenzi).
}

oxidation (see [5]). $\mathrm{O}_{2}$ and $\mathrm{NO}$ derivatives react also with amino acid residues (e.g., Cys, Met, Trp, and Tyr) modulating protein metabolism and functions (see [19-21]).

The reaction of $\mathrm{CO}$ with heme-Fe(II)-proteins has received great attention due to its high toxicity (see [22]); recently, $\mathrm{CO}$ has been reported to act also as a second messenger (see $[23,24])$. Furthermore, $\mathrm{CO}$ represents an invaluable model system for investigating diatomic ligand binding to metal centers (i.e., the heme) (see $[5,6,8,9,25]$ ). Values of the equilibrium constant for $\mathrm{CO}$ binding to heme-Fe(II)-proteins range between $10^{7}$ and $10^{10} \mathrm{M}^{-1}$. Values of the second-order rate constant for heme-Fe(II)-protein carbonylation range between $10^{4}$ and $10^{7} \mathrm{M}^{-1} \mathrm{~s}^{-1}$. Values of the first-order dissociation rate constant for heme$\mathrm{Fe}(\mathrm{II})$-protein decarbonylation range between $10^{-2}$ and $10^{-4} \mathrm{~s}^{-1}$ (see $[5,6,8,9,25-28]$ ). CO binding to heme-Fe(II)proteins is mainly modulated by heme proximal effects. In particular, the very high carbonylation rate observed 
in some penta-coordinate heme-proteins has been attributed to the close location of the $\mathrm{Fe}(\mathrm{II})$-atom with respect to the heme plane. This can be also achieved by cleavage of the HisF8-Fe heme proximal bond in slow carbonylating penta-coordinate heme-proteins since it leads to fast reacting tetra-coordinated heme-protein systems (see [29-34]).

Values of the second-order rate constant for $\mathrm{CO}$ binding to heme-Fe(II)-proteins (i.e., $\left.k_{\mathrm{on}(\mathrm{CO})}\right)$ are easy to determine by the dependence of the observed binding rate constant on the $\mathrm{CO}$ concentration. On the other hand, values of the first-order rate constant for $\mathrm{CO}$ dissociation from heme$\mathrm{Fe}(\mathrm{II})-\mathrm{CO}$ complexes (i.e., $\left.k_{\mathrm{off}(\mathrm{CO})}=k_{\mathrm{obs}(\mathrm{CO})}-k_{\mathrm{on}(\mathrm{CO})} \times[\mathrm{CO}]\right)$ are very difficult to be determined by extrapolating to $[\mathrm{CO}]=0$ the dependence of the observed binding rate constant (i.e., $k_{\mathrm{obs}(\mathrm{CO})}$ ) on the $\mathrm{CO}$ concentration because of the very low value of $k_{\mathrm{off}(\mathrm{CO})}$ and the large difference with respect to $k_{\mathrm{obs}(\mathrm{CO})}$. Therefore, appropriate methods to determine the first-order rate constant for $\mathrm{CO}$ dissociation from heme-Fe(II)-CO species can be through experiments in which either (i) the heme-Fe(II)-CO complex is oxidized by ferricyanide or (ii) $\mathrm{CO}$ is replaced by $\mathrm{NO}$, in both cases under the assumption that experimental conditions satisfy the requirement that the rate limiting step is represented by $\mathrm{CO}$ dissociation from the heme-Fe(II)-CO adduct. Furthermore, the high affinity of $\mathrm{CO}$ renders hard to determine the equilibrium constant for heme$\mathrm{Fe}(\mathrm{II})$-protein $\quad$ carbonylation $\quad\left(K_{(\mathrm{CO})}=k_{\mathrm{on}(\mathrm{CO})} / k_{\mathrm{off}(\mathrm{CO})}\right)$ (see $[5,25,35,36])$.

The redox potential of peroxynitrite (see [37]) suggests that this chemical is able to oxidize carbonylated heme$\mathrm{Fe}(\mathrm{II})$-proteins, as already reported for heme-Fe(II)- $\mathrm{O}_{2}$ and heme-Fe(II)-NO complexes (see [18,38,39]). However, while peroxynitrite-mediated oxidation of heme-Fe(II)- $\mathrm{O}_{2}$ complexes requires $\mathrm{O}_{2}$ dissociation, followed by a rapid oxidation of the transient heme-Fe(II) derivative (see $[18,38])$, peroxynitrite-mediated oxidation of heme-Fe(II)NO complexes involves the transient heme-Fe(III)-NO species, followed by 'NO dissociation and formation of the heme-Fe(III) derivative (see [18,39]).

Here, kinetics of peroxynitrite-mediated oxidation of horse heart $\mathrm{Mb}(\mathrm{II})-\mathrm{CO}$ is reported for the first time. The coincidence of values of the first-order rate constant for peroxynitrite-induced oxidation of $\mathrm{Mb}(\mathrm{II})-\mathrm{CO}$ (i.e., h) and of the first-order rate constant for $\mathrm{Mb}$ (II)-CO decarbonylation (i.e., $k_{\mathrm{off}(\mathrm{CO})}$ ) indicates that $\mathrm{CO}$ dissociation represents the rate limiting step of peroxynitrite-mediated oxidation of $\mathrm{Mb}(\mathrm{II})-\mathrm{CO}$.

\section{Materials and methods}

Ferric horse heart $\mathrm{Mb}$ (purified by crystallization; $\mathrm{Mb}(\mathrm{III})$ ) was obtained from Sigma-Aldrich (St. Louis, MO, USA). The Mb(II)-CO (final concentration $3.2 \times 10^{-6} \mathrm{M}$ ) solution was prepared as follows. $\mathrm{Mb}(\mathrm{II})$ was obtained by reducing $\mathrm{Mb}$ (III) with sodium dithionite. The excess of dithionite and by-products were removed by passing the protein solution through a Sephadex G-10 gel filtration column (Amersham Biosciences Europe $\mathrm{GmbH}$, Freiburg, Germany) equilibrated in air with $5.0 \times 10^{-2} \mathrm{M}$ phosphate buffer, $\mathrm{pH} 7.2$, at $20.0^{\circ} \mathrm{C}[5]$. Then, the $\mathrm{Mb}(\mathrm{II})-$
$\mathrm{O}_{2}$ solution was gently degassed and the $\mathrm{CO}$ (final concentration, $5.0 \times 10^{-4} \mathrm{M}$ ) solution was added, under anaerobic conditions [5,25].

$\mathrm{CO}$ was purchased from Linde AG (Höllriegelskreuth, Germany). 'NO (from Aldrich Chemical Co., Milwaukee, WI, USA) was purified by flowing through an $\mathrm{NaOH}$ column in order to remove acidic nitrogen oxides. The $\mathrm{CO}$ and $\mathrm{NO}$ solutions were prepared by keeping in a closed vessel the $5.0 \times 10^{-2} \mathrm{M}$ phosphate buffer solution $(\mathrm{pH}=7.2)$ under $\mathrm{CO}$ or 'NO at $P=760.0 \mathrm{~mm} \mathrm{Hg}$ anaerobically $\left(T=20.0^{\circ} \mathrm{C}\right)$. The solubility of $\mathrm{CO}$ and $\mathrm{NO}$ in the aqueous buffered solution is $1.03 \times 10^{-3}$ and $2.05 \times 10^{-3} \mathrm{M}$, respectively, at $P=760.0 \mathrm{~mm} \mathrm{Hg}$ and $T=20.0^{\circ} \mathrm{C}$ [5].

Peroxynitrite was prepared from either $\mathrm{KO}_{2}$ and $\mathrm{NO}$ or from $\mathrm{HNO}_{2}$ and $\mathrm{H}_{2} \mathrm{O}_{2}$ [40,41]. Decomposed peroxynitrite was obtained by acidification of the peroxynitrite solution [37]. The solutions of the experiments in the presence of $\mathrm{CO}_{2}$ were prepared by adding the required amount of a $5.0 \times 10^{-1} \mathrm{M} \mathrm{NaHCO}_{3}$ solution [42].

All the other products (from Merck AG, Darmstadt, Germany, or Sigma-Aldrich, St. Louis, MO, USA) were of analytical grade and used without purification unless stated.

The value of the first-order rate constant for peroxynitrite-induced conversion of $\mathrm{Mb}(\mathrm{II})-\mathrm{CO}$ to $\mathrm{Mb}(\mathrm{III})$ (i.e., $h$ ) was determined by mixing the $\mathrm{Mb}(\mathrm{II})-\mathrm{CO}$ (final concentration, $3.2 \times 10^{-6} \mathrm{M}$ ) solution with the peroxynitrite (final concentration, $1.0 \times 10^{-4}$ to $5.0 \times 10^{-4} \mathrm{M}$ ) solution under anaerobic conditions, at $\mathrm{pH}=7.2\left(5.0 \times 10^{-2} \mathrm{M}\right.$ phosphate buffer $)$ and $T=20.0^{\circ} \mathrm{C}$; no gaseous phase was present (see [18]). Kinetics was monitored between 360 and $460 \mathrm{~nm}$.

The time course of peroxynitrite-induced conversion of $\mathrm{Mb}(\mathrm{II})-\mathrm{CO}$ to $\mathrm{Mb}$ (III) was fitted to a single exponential process according to the minimum reaction mechanism represented by Scheme 1 (Table 1).

The value of $h$ has been determined from data analysis, according to Eq. (1) [5]:

$[\mathrm{Fe}(\mathrm{II})-\mathrm{CO}]_{\mathrm{t}}=[\mathrm{Fe}(\mathrm{II})-\mathrm{CO}]_{\mathrm{i}} \times \mathrm{e}^{-h \times t}$

The value of the first-order rate constant for $\mathrm{CO}$ dissociation from $\mathrm{Mb}(\mathrm{II})-\mathrm{CO}$ (i.e., for $\mathrm{CO}$ replacement by $\left.{ }^{\mathrm{NO}} ; k_{\mathrm{off}(\mathrm{CO})}\right)$ was determined by mixing the $\mathrm{Mb}(\mathrm{II})-\mathrm{CO}$ (final concentration, $3.2 \times 10^{-6} \mathrm{M}$ ) solution with the NO-dithionite (final concentration, $1.0 \times 10^{-4}$ to $5.0 \times 10^{-4}$, and $2.0 \times 10^{-5} \mathrm{M}$, respectively) solution under anaerobic conditions, at $\mathrm{pH}=7.2\left(5.0 \times 10^{-2} \mathrm{M}\right.$ phosphate buffer $)$, and $T=20.0^{\circ} \mathrm{C}$; no gaseous phase was present (see [25]). Kinetics was monitored between 360 and $460 \mathrm{~nm}$.

The time course of $\mathrm{CO}$ dissociation from $\mathrm{Mb}(\mathrm{II})-\mathrm{CO}$ (i.e., of $\mathrm{CO}$ replacement by ${ }^{\circ} \mathrm{NO}$ ) was fitted to a single exponential process according to the minimum reaction mechanism represented by Scheme 2 (Table 1) [25].

The value of $k_{\text {off(CO) }}$ has been determined from data analysis, according to Eq. (2) [5]:

$[\mathrm{Fe}(\mathrm{II})-\mathrm{CO}]_{\mathrm{t}}=[\mathrm{Fe}(\mathrm{II})-\mathrm{CO}]_{\mathrm{i}} \times \mathrm{e}^{-k_{\text {off }(\mathrm{CO})} \times t}$

The difference optical absorption spectra in the Soret region of $\mathrm{Mb}(\mathrm{II})-\mathrm{CO}$ minus $\mathrm{Mb}(\mathrm{III})$ and of $\mathrm{Mb}(\mathrm{II})-\mathrm{CO}$ minus $\mathrm{Mb}(\mathrm{II})-\mathrm{NO}$ were obtained under steady-state conditions by subtracting the absorbance of $\mathrm{Mb}(\mathrm{III})$ from that of $\mathrm{Mb}(\mathrm{II})-\mathrm{CO}$ and of $\mathrm{Mb}(\mathrm{II})-\mathrm{NO}$ from that of $\mathrm{Mb}(\mathrm{II})$ $\mathrm{CO}$, respectively.

The kinetic difference optical absorption spectra in the Soret region of $\mathrm{Mb}(\mathrm{II})-\mathrm{CO}$ minus $\mathrm{Mb}(\mathrm{III})$ and of $\mathrm{Mb}(\mathrm{II})-\mathrm{CO}$ minus $\mathrm{Mb}(\mathrm{II})-\mathrm{NO}$ were reconstructed from the difference optical absorption spectrum of $\mathrm{Mb}(\mathrm{III})$ minus $\mathrm{Mb}(\mathrm{III})$ and of $\mathrm{Mb}(\mathrm{II})-\mathrm{NO}$ minus $\mathrm{Mb}(\mathrm{II})-\mathrm{NO}\left(\Delta \varepsilon=0.0 \mathrm{M}^{-1} \mathrm{~cm}^{-1}\right)$ obtained under steady-state conditions plus the absorbance changes of the processes $\mathrm{Mb}(\mathrm{II})-\mathrm{CO}+$ peroxynitrite $\rightarrow \mathrm{Mb}(\mathrm{III})+\mathrm{CO}$ (see Scheme 1) and $\mathrm{Mb}(\mathrm{II})-\mathrm{CO}+{ }^{\cdot} \mathrm{NO} \rightarrow \mathrm{Mb}(\mathrm{II})-\mathrm{NO}+\mathrm{CO}$ (see Scheme 2 ), respectively.

$h$

$\mathrm{Mb}(\mathrm{II})-\mathrm{CO}+$ peroxynitrite $\rightarrow \mathrm{Mb}(\mathrm{III})+\mathrm{CO}$

Scheme 1. 
Table 1

Minimum reaction mechanisms for peroxynitrite-mediated oxidation of horse heart $\mathrm{Mb}(\mathrm{II})$ derivatives ${ }^{\mathrm{a}}$

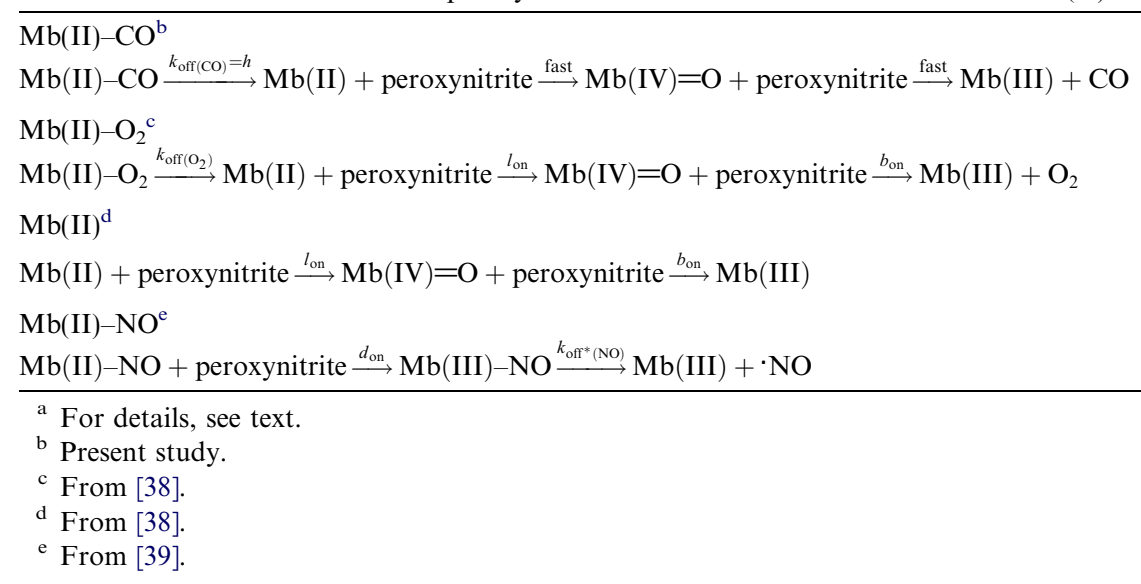

$$
\begin{gathered}
k_{\text {off(CO) }} \\
\mathrm{Mb}(\mathrm{II})-\mathrm{CO}+{ }^{\bullet} \mathrm{NO} \rightarrow \mathrm{Mb}(\mathrm{II})-\mathrm{NO}+\mathrm{CO}
\end{gathered}
$$

Scheme 2.

The results are given as mean values of at least three experiments plus or minus the corresponding standard deviation. All data were analyzed using the Matlab program (The Math Works Inc., Natick, MA, USA).

\section{Results and discussion}

Mixing of the $\mathrm{Mb}(\mathrm{II})-\mathrm{CO}$ and peroxynitrite solutions causes a shift of the optical absorption maximum of the Soret band from $424 \mathrm{~nm}$ (i.e., $\mathrm{Mb}(\mathrm{II})-\mathrm{CO}$ ) to $408 \mathrm{~nm}$ (i.e., $\mathrm{Mb}(\mathrm{III})$ ) and a change of the extinction coefficient from $\varepsilon_{424 \mathrm{~nm}}=2.07 \times 10^{5} \mathrm{M}^{-1} \mathrm{~cm}^{-1}$ (i.e., $\left.\mathrm{Mb}(\mathrm{II})-\mathrm{CO}\right)$ to $\varepsilon_{408 \mathrm{~nm}}=1.88 \times 10^{5} \mathrm{M}^{-1} \mathrm{~cm}^{-1}$ (i.e., $\mathrm{Mb}(\mathrm{III})$ ). The optical absorption spectra of $\mathrm{Mb}(\mathrm{II})-\mathrm{CO}$ and of $\mathrm{Mb}(\mathrm{III})$ obtained here correspond to those reported in the literature (see [5]).

Over the whole peroxynitrite concentration range explored (final concentration, $1.0 \times 10^{-4}$ to $5.0 \times 10^{-4} \mathrm{M}$ ), the time course for the peroxynitrite-mediated oxidation of $\mathrm{Mb}(\mathrm{II})-\mathrm{CO}$ corresponds to a mono-exponential process for more than $95 \%$ of its course (Fig. 1, panel A). Values of the pseudo-first-order rate constant for $\mathrm{Mb}$ (III) formation (i.e., h) are wavelength- and [peroxynitrite]-independent (Fig. 1, panel B). The average value of $h$ is $(1.2 \pm 0.2) \times 10^{-2} \mathrm{~s}^{-1}$. These data indicate that the reaction of $\mathrm{Mb}(\mathrm{II})-\mathrm{CO}$ with an excess of peroxynitrite leads to the oxidation of the heme-Fe(II) atom and to the generation of $\mathrm{Mb}(\mathrm{III})$ without involving transient species. As expected, decomposed peroxynitrite does not oxidize $\mathrm{Mb}(\mathrm{II})-\mathrm{CO}$.

Although $\mathrm{CO}_{2}$ reacts with peroxynitrite leading to high reactive and selective oxidant species $\mathrm{CO}_{3}{ }^{-{ }^{-}}$and ${ }^{\circ} \mathrm{NO}_{2}$ (see $[20,37]), \mathrm{CO}_{2}$ (whose concentration corresponds to that of the buffered $5.0 \times 10^{-1} \mathrm{M} \mathrm{NaHCO} 3$ solution) does not affect kinetics of peroxynitrite-mediated oxidation of $\mathrm{Mb}(\mathrm{II})-\mathrm{CO}$, under all the experimental conditions (data not shown).
Mixing of the $\mathrm{Mb}(\mathrm{II})-\mathrm{CO}$ and $\mathrm{NO}$-dithionite solutions causes a shift of the optical absorption maximum of the Soret band from $424 \mathrm{~nm}$ (i.e., $\mathrm{Mb}(\mathrm{II})-\mathrm{CO}$ ) to $416 \mathrm{~nm}$ (i.e., $\mathrm{Mb}(\mathrm{II})-\mathrm{NO}$ ) and a change of the extinction coefficient from $\varepsilon_{424 \mathrm{~nm}}=2.07 \times 10^{5} \mathrm{M}^{-1} \mathrm{~cm}^{-1}$ (i.e., $\left.\mathrm{Mb}(\mathrm{II})-\mathrm{CO}\right)$ to $\varepsilon_{416 \mathrm{~nm}}=1.32 \times 10^{5} \mathrm{M}^{-1} \mathrm{~cm}^{-1}$ (i.e., $\left.\mathrm{Mb}(\mathrm{II})-\mathrm{NO}\right)$. The optical absorption spectrum of $\mathrm{Mb}(\mathrm{II})-\mathrm{CO}$ obtained here corresponds to that reported in the literature (see [5]).

Over the whole $\mathrm{NO}$ concentration range explored (final concentration, $1.0 \times 10^{-4}$ to $5.0 \times 10^{-4} \mathrm{M}$ ), the time course for the replacement of $\mathrm{CO}$ by $\mathrm{NO}$ (i.e., for the formation of $\mathrm{Mb}(\mathrm{II})-\mathrm{NO}$ ) corresponds to a mono-exponential process for more than $95 \%$ of its course (Fig. 1, panel C). Values of the first-order rate constant for $\mathrm{Mb}(\mathrm{II})-\mathrm{CO}$ decarbonylation (i.e., for $\mathrm{Mb}(\mathrm{II})-\mathrm{NO}$ formation; $k_{\mathrm{off}(\mathrm{CO})}$ ) are wavelength- and ['NO]-independent (Fig. 1, panel D). The average value of $k_{\text {off(CO) }}$ is $(1.4 \pm 0.2) \times 10^{-2} \mathrm{~s}^{-1}$. The $k_{\mathrm{off}(\mathrm{CO})}$ value here reported is in excellent agreement with that reported in the literature [5]. These data indicate that the reaction of $\mathrm{Mb}(\mathrm{II})-\mathrm{CO}$ with an excess of 'NO-dithionite leads to the formation of $\mathrm{Mb}(\mathrm{II})-\mathrm{NO}$ without involving transient species, as previously reported (see [25]).

The coincidence of values of $h$ and $k_{\mathrm{off}(\mathrm{CO})}$ (Fig. 1 and Table 2) suggests that peroxynitrite-mediated oxidation of $\mathrm{Mb}(\mathrm{II})-\mathrm{CO}$ occurs with a reaction mechanism in which $\mathrm{CO}$ dissociation represents the rate limiting step; therefore, oxidation by peroxynitrite takes place with unliganded $\mathrm{Mb}(\mathrm{II})$. Accordingly, $\mathrm{CO}_{2}$, facilitating peroxynitrite action (see $[20,37]$ ), does not affect $\mathrm{Mb}(\mathrm{II})-\mathrm{CO}$ oxidation. This mechanism is reminiscent of that reported for ferricyanide-induced oxidation of $\mathrm{Mb}(\mathrm{II})$ CO (see [36]).

The mechanism postulated for peroxynitrite-induced oxidation of $\mathrm{Mb}(\mathrm{II})-\mathrm{CO}$ holds also in the case of $\mathrm{Mb}(\mathrm{II})-\mathrm{O}_{2}$ and $\mathrm{Mb}(\mathrm{II})$, in all cases peroxynitrite appears to react with the $\mathrm{Mb}(\mathrm{II})$ species (see Table 1 ). Therefore, the peroxynitrite-mediated oxidation of $\mathrm{Mb}(\mathrm{II})-\mathrm{CO}$ and $\mathrm{Mb}(\mathrm{II})-\mathrm{O}_{2}$ occurs with a reaction mechanism in which $\mathrm{CO}$ or $\mathrm{O}_{2}$, that is initially bound to the heme-Fe(II)-atom, dissociates from the carbonylated or oxygenated heme- 

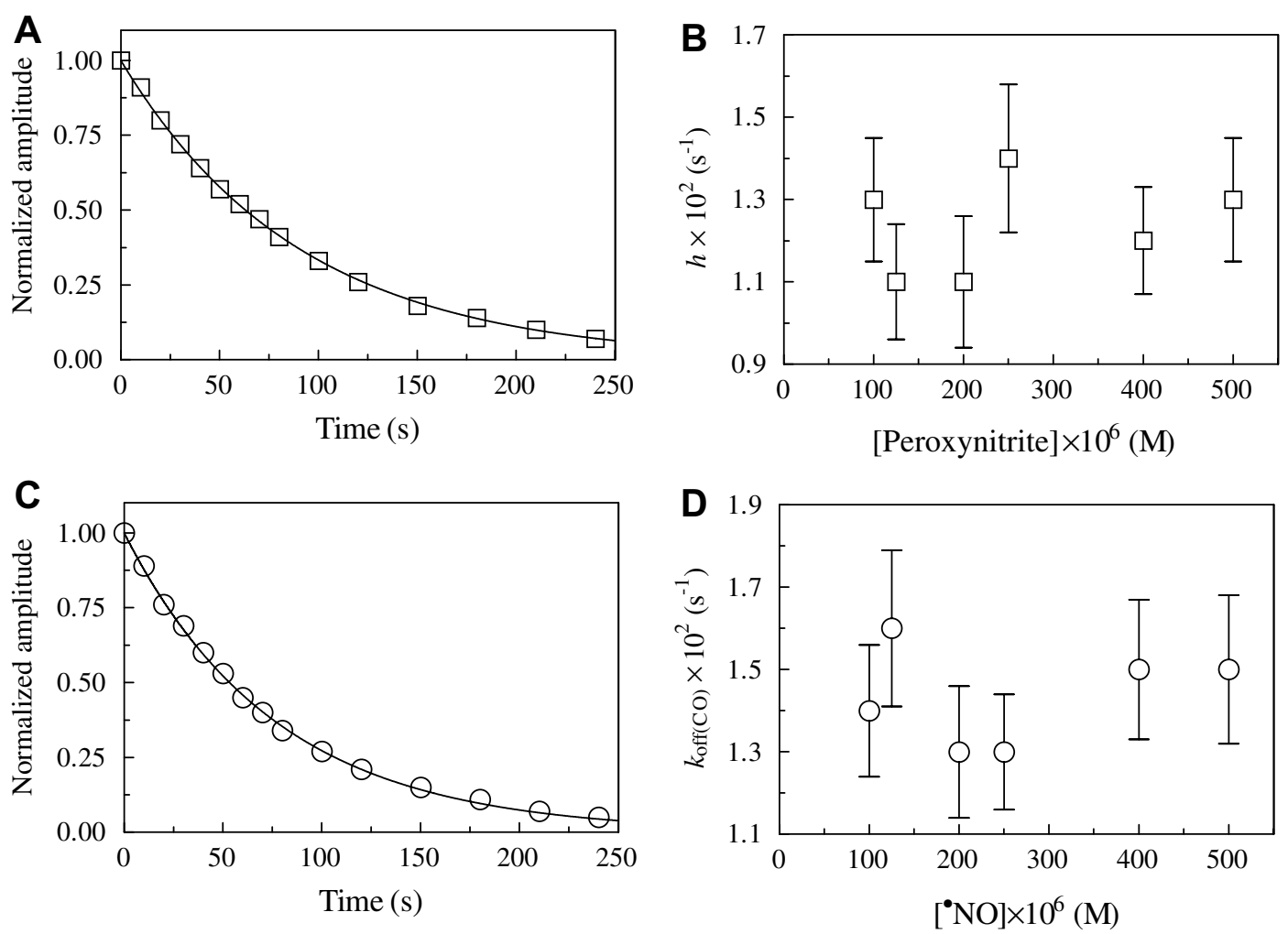

Fig. 1. Kinetics of peroxynitrite-mediated oxidation of $\mathrm{Mb}(\mathrm{II})-\mathrm{CO}$ and of $\mathrm{Mb}(\mathrm{II})-\mathrm{CO}$ decarbonylation, at pH 7.2 and $20.0^{\circ} \mathrm{C}$. (A) Normalized averaged time course of the peroxynitrite-mediated conversion of $\mathrm{Mb}(\mathrm{II})-\mathrm{CO}$ to $\mathrm{Mb}(\mathrm{III})$. The time course analysis according to Eq. (1) allowed to determine the following value of $h=1.1 \times 10^{-2} \mathrm{~s}^{-1}$. The peroxynitrite concentration was $2.0 \times 10^{-4} \mathrm{M}$. (B) Dependence of $h$ for peroxynitrite-induced conversion of $\mathrm{Mb}(\mathrm{II})-\mathrm{CO}$ to $\mathrm{Mb}$ (III) on peroxynitrite concentration. The average value of $h$ is $(1.2 \pm 0.2) \times 10^{-2} \mathrm{~s}^{-1}$. (C) Normalized averaged time course of $\mathrm{Mb}$ (II)$\mathrm{CO}$ decarbonylation. The time course analysis according to Eq. (2) allowed to determine the following value of $k_{\mathrm{off}(\mathrm{CO})}=1.3 \times 10^{-2} \mathrm{~s}^{-1}$. The ${ }^{-\mathrm{NO}}$ and

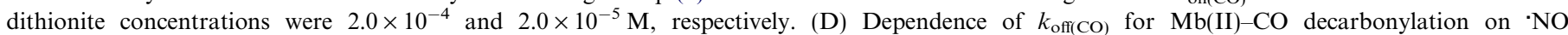
concentration. The average value of $k_{\mathrm{off}(\mathrm{CO})}$ is $(1.4 \pm 0.2) \times 10^{-2} \mathrm{~s}^{-1}$. The $\mathrm{Mb}(\mathrm{II})-\mathrm{CO}$ concentration was $3.2 \times 10^{-6} \mathrm{M}$.

Table 2

Kinetic parameters for peroxynitrite-mediated oxidation of horse heart $\mathrm{Mb}(\mathrm{II})$ derivatives ${ }^{\mathrm{a}}$

\begin{tabular}{llll}
\hline Heme-protein & Kinetic parameters & & \\
\hline $\mathrm{Mb}(\mathrm{II})-\mathrm{CO}^{\mathrm{b}}$ & $k_{\text {off(CO) }}=1.4 \times 10^{-2} \mathrm{~s}^{-1}$ & $h=1.2 \times 10^{-2} \mathrm{~s}^{-1}$ & $b_{\text {on }}=2.2 \times 10^{4} \mathrm{M}^{-1} \mathrm{~s}^{-1 \mathrm{~d}}$ \\
$\mathrm{Mb}(\mathrm{II})-\mathrm{O}_{2}$ & $k_{\text {off( }}=1.1 \times 10^{1} \mathrm{~s}^{-1 \mathrm{c}}$ & $b_{\text {on }}=2.3 \times 10^{4} \mathrm{M}^{-1} \mathrm{~s}^{-1 \mathrm{~d}}$ & \\
$\mathrm{Mb}(\mathrm{II})^{\mathrm{e}}$ & $l_{\text {on }} \sim 10^{6} \mathrm{M}^{-1} \mathrm{~s}^{-1}$ & $\mathrm{M}^{-1} \mathrm{~s}^{-1}$ & \\
$\mathrm{Mb}(\mathrm{II})-\mathrm{NO}^{\mathrm{f}}$ & $d_{\text {on }}=3.1 \times 10^{4} \mathrm{M}^{-1} \mathrm{~s}^{-1}$ & $k_{\text {off }}^{*}(\mathrm{NO}) \sim 1.2 \times 10^{1} \mathrm{~s}^{-1}$ & \\
\hline
\end{tabular}

\footnotetext{
${ }^{a}$ Reaction mechanisms are reported in Table 1. For details, see text.

${ }^{\mathrm{b}} \mathrm{pH}=7.2$ and $20.0^{\circ} \mathrm{C}$. Present study.

${ }^{\mathrm{c}} \mathrm{pH}=7.0$ and $20.0^{\circ} \mathrm{C}$. From [5].

d $\mathrm{pH}=7.3$ and $20.0^{\circ} \mathrm{C}$. From [38].

e $\mathrm{pH}=7.5$ and $20.0^{\circ} \mathrm{C}$. From [38].

${ }^{\mathrm{f}} \mathrm{pH}=7.5$ and $20.0^{\circ} \mathrm{C}$. From [39].
}

$\mathrm{Fe}(\mathrm{II})$-protein. In the second step, deoxygenated $\mathrm{Mb}(\mathrm{II})$ reacts with peroxynitrite by way of the transient $\mathrm{Mb}(\mathrm{IV})=\mathrm{O}$ species that precedes the $\mathrm{Mb}(\mathrm{III})$ formation (see Tables 1 and 2) (see $[18,38]$ ).

Despite the common oxidation mechanism (see Table 1), peroxynitrite-induced oxidation of $\mathrm{Mb}(\mathrm{II})-\mathrm{CO}$ and $\mathrm{Mb}(\mathrm{II})-\mathrm{O}_{2}$ displays different features, which are related to the relative velocity of the various steps leading to the $\mathrm{Mb}$ (III) species [38]. In fact, the first-order rate constant for $\mathrm{CO}$ dissociation from $\mathrm{Mb}(\mathrm{II})-\mathrm{CO}$ (i.e., $\left.k_{\mathrm{off}(\mathrm{CO})}\right)$ is lower by about one-order of magnitude than kinetics reported for peroxynitrite-induced oxidation of the transient $\mathrm{Mb}(\mathrm{II})$ species [38] (Tables 1 and 2), impairing the accumulation of the intermediate $\mathrm{Mb}(\mathrm{II})$ species. On the other hand, the first-order rate constant for $\mathrm{O}_{2}$ dissociation from $\mathrm{Mb}(\mathrm{II})-\mathrm{O}_{2}$ (i.e., $\left.k_{\mathrm{off}(\mathrm{O} 2)}\right)$ [5] is higher by about one-order of magnitude than kinetics reported for peroxynitrite-induced oxidation of the transient $\mathrm{Mb}(\mathrm{II})$ species [38] (Tables 1 and 2); therefore, $\mathrm{Mb}(\mathrm{II})$ accumulates rapidly before being oxidized by peroxyni- 
trite and it can be detected [38]. These data indicate that the different values of $k_{\mathrm{off}(\mathrm{CO})}$ and $k_{\mathrm{off(}(\mathrm{O} 2)}$ are the crucial point from which the different rate limiting step of peroxynitrite-induced oxidation of $\mathrm{Mb}(\mathrm{II})-\mathrm{CO}$ and $\mathrm{Mb}(\mathrm{II})-\mathrm{O}_{2}$ originates.

Peroxynitrite-mediated oxidation of $\mathrm{Mb}(\mathrm{II})-\mathrm{NO}$ follows a completely different mechanism (Tables 1 and 2), involving the transient $\mathrm{Mb}(\mathrm{III})-\mathrm{NO}$ species. This reflects the capability of NO to bind both heme-Fe(II)- and heme$\mathrm{Fe}(\mathrm{III})$-proteins albeit with different thermodynamic and kinetic parameters (see [5,8-12]). At low $\mathrm{NO}$ concentration (i.e., under conditions where [ $\mathrm{NO}]$ is sufficient to nitrosylate $\mathrm{Mb}$ (II) but not $\mathrm{Mb}(\mathrm{III})$ ), the dissociation of the transient $\mathrm{Mb}(\mathrm{III})-\mathrm{NO}$ species (i.e., $\mathrm{Mb}(\mathrm{III})$ formation) takes place, $\mathrm{Mb}(\mathrm{III})-\mathrm{NO}$ denitrosylation kinetics (indicated by $k_{\text {off }}{ }^{*}$ (NO) in Tables 1 and 2) representing the rate limiting step. At high 'NO concentration (i.e., under conditions where [ $\mathrm{NO}$ ] nitrosylates both $\mathrm{Mb}(\mathrm{II})$ and $\mathrm{Mb}(\mathrm{III})$ ), the dissociation of the transient $\mathrm{Mb}$ (III)-NO species (i.e., $\mathrm{Mb}$ (III) formation) does not occur, $\mathrm{Mb}$ (III)-NO representing the final product (see [18,39]).

As a whole, data here reported represent the first quantitative analysis of peroxynitrite-mediated oxidation of $\mathrm{Mb}(\mathrm{II})-\mathrm{CO}$ which appears to be limited by decarbonylation kinetics. Peroxynitrite-induced oxidation of $\mathrm{Mb}(\mathrm{II})-$ $\mathrm{CO}$ and $\mathrm{Mb}(\mathrm{II})-\mathrm{O}_{2}$ is preceded by dissociation of $\mathrm{CO}$ and $\mathrm{O}_{2}$, respectively, values of the second-order rate constants for peroxynitrite-mediated oxidation of $\mathrm{Mb}(\mathrm{II})-\mathrm{O}_{2}$ and $\mathrm{Mb}(\mathrm{II})$ (i.e., $l_{\mathrm{on}}$ and $b_{\mathrm{on}}$ ) are similar (see Table 2). In contrast, peroxynitrite-mediated oxidation of $\mathrm{Mb}$ (III)$\mathrm{NO}$ does not require the preliminary dissociation of $\mathrm{NO}$. Then, $\mathrm{Mb}(\mathrm{III})-\mathrm{NO}$ undergoes $\mathrm{NO}$ dissociation (i.e., $\mathrm{Mb}$ (III) formation), at low ['NO] only (see [18,39]).

Lastly, the different mechanisms describing peroxynitrite-induced oxidation of $\mathrm{Mb}(\mathrm{II})-\mathrm{CO}, \mathrm{Mb}(\mathrm{II})-\mathrm{O}_{2}$, and $\mathrm{Mb}(\mathrm{II})-\mathrm{NO}$ (Table 1) (see present study and $[38,39]$ ) are important since peroxynitrite-mediated oxidation of ferrous carbonylated, oxygenated, and nitrosylated oxygen carriers may be used to determine the first-order rate constant of $\mathrm{CO}, \mathrm{O}_{2}$, and $\mathrm{NO}$ dissociation, respectively. However, some caution is demanded since: (i) ligand dissociation may be faster than heme-Fe(II)-atom oxidation (as in the case of $\mathrm{Mb}(\mathrm{II})-\mathrm{O}_{2}$ ) [38], and (ii) peroxynitrite may be able to directly oxidize the heme$\mathrm{Fe}(\mathrm{II})$-atom without requiring the dissociation of the sixth ligand (as in the case of $\mathrm{Mb}(\mathrm{II})$ )-NO) [39]. As a consequence, for the measurement of the first-order dissociation rate constant of $\mathrm{Mb}(\mathrm{II})-\mathrm{CO}, \mathrm{Mb}(\mathrm{II})-\mathrm{O}_{2}$, and $\mathrm{Mb}(\mathrm{II})-\mathrm{NO}$ it is better to monitor ligand binding competition for the heme-Fe(II)-atom (e.g., CO versus NO) (see [25]).

\section{Acknowledgments}

This work was partially supported by grants from the Ministry for University and Research of Italy (University 'Roma Tre', Roma, Italy, 'CLAR 2007' to P.A., and
University of Roma 'Tor Vergata', Roma, Italy, ' $60 \%$ ' to M.C.) and from the Ministry for Health of Italy (National Institute for Infectious Diseases I.R.C.C.S. 'Lazzaro Spallanzani', Roma, Italy, 'Ricerca Corrente 2006' to P.A.).

\section{References}

[1] I. Moura, J.J. Moura, Structural aspects of denitrifying enzymes, Curr. Opin. Chem. Biol. 5 (2001) 168-175.

[2] U. Deppenmeier, The unique biochemistry of methanogenesis, Prog. Nucleic Acid Res. Mol. Biol. 71 (2002) 223-283.

[3] G. Chen, H. Zhu, Y. Zhang, Soil microbial activities and carbon and nitrogen fixation, Res. Microbiol. 154 (2003) 393-398.

[4] E. Gnaiger, Oxygen conformance of cellular respiration. A perspective of mitochondrial physiology, Adv. Exp. Med. Biol. 543 (2003) $39-55$.

[5] E. Antonini, M. Brunori, Hemoglobin and Myoglobin in their Reactions with Ligands, North-Holland Publishing Co., Amsterdam, 1971.

[6] M.F. Perutz, Regulation of oxygen affinity of hemoglobin: influence of structure of the globin on the heme iron, Annu. Rev. Biochem. 48 (1979) 327-386.

[7] K. Kobayashi, M. Tamura, K. Hayashi, Kinetic analysis of the recombination of NO with ferrihemoproteins by the flash photolysis method, Biochemistry 21 (1982) 729-732.

[8] M. Brunori, M. Coletta, P. Ascenzi, M. Bolognesi, Kinetic control of ligand binding processes in hemoproteins, J. Mol. Liquids 42 (1989) $175-193$.

[9] M. Bolognesi, D. Bordo, M. Rizzi, C. Tarricone, P. Ascenzi, Nonvertebrate hemoglobins: structural bases for reactivity, Prog. Biophys. Mol. Biol. 68 (1997) 29-68.

[10] W.R. Scheidt, M.K. Ellison, The synthetic and structural chemistry of heme derivatives with nitric oxide ligands, Acc. Chem. Res. 32 (1999) 350-359.

[11] P.J. Farmer, F. Sulc, Coordination chemistry of the HNO ligand with hemes and synthetic coordination complexes, J. Inorg. Biochem. 99 (2005) 166-184.

[12] P. Ascenzi, A. Bellelli, M. Coletta, A. Colosimo, G. Falcioni, G.M. Giacometti, R. Ippoliti, L. Zolla, B. Giardina, Multiple strategies for $\mathrm{O}_{2}$ transport: from simplicity to complexity, IUBMB life 59 (2007) $600-616$.

[13] D. Bickar, C. Bonaventura, J. Bonaventura, Carbon monoxide-driven reduction of ferric heme and heme proteins, J. Biol. Chem. 259 (1984) 10777-10783.

[14] A. Boffi, C. Bonaventura, J. Bonaventura, R. Cashon, E. Chiancone, Oxidized dimeric Scapharca inaequivalvis: CO-driven perturbation of the redox equilibrium, J. Biol. Chem. 266 (1991) 17898-17903.

[15] M. Hoshino, M. Maeda, R. Konishi, H. Seki, P.C. Ford, Studies on the reaction mechanism for reductive nitrosylation of ferrihemoproteins in buffer solutions, J. Am. Chem. Soc. 118 (1996) 57025707.

[16] P.C. Ford, B.O. Fernandez, M.D. Lim, Mechanisms of reductive nitrosylation in iron and copper models relevant to biological systems, Chem. Rev. 105 (2005) 2439-2455.

[17] P. Ascenzi, A. Bocedi, G. Antonini, M. Bolognesi, M. Fasano, Reductive nitrosylation and peroxynitrite-mediated oxidation of heme-hemopexin, FEBS J. 274 (2007) 551-562.

[18] P. Ascenzi, P. Visca, Scavenging of reactive nitrogen species by mycobacterial truncated hemoglobins, Methods Enzymol. 436 (2008), doi:10.1016/S0076-6879(08)36018-2.

[19] D.T. Hess, A. Matsumoto, S.O. Kim, H.E. Marshall, J.S. Stamler, Protein $S$-nitrosylation: purview and parameters, Nat. Rev. Mol. Cell Biol. 6 (2005) 150-166.

[20] P. Ascenzi, A. Bocedi, P. Visca, M. Minetti, E. Clementi, Does $\mathrm{CO}_{2}$ modulate peroxynitrite specificity? IUBMB Life 58 (2006) 611-613. 
[21] K. Bian, Y. Ke, Y. Kamisaki, F. Murad, Proteomic modification by nitric oxide, J. Pharmacol. Sci. 101 (2006) 271-279.

[22] L.W. Kao, K.A. Nanagas, Toxicity associated with carbon monoxide, Clin. Lab. Med. 26 (2006) 99-125.

[23] D. Morse, J. Sethi, A.M. Choi, Carbon monoxide-dependent signaling, Crit. Care Med. 30 (Suppl. 1) (2002) S12-S17.

[24] B.S. Zuckerbraun, B.Y. Chin, M. Bilban, J. de Costa d'Avila, J. Rao, T.R. Billiar, L.E. Otterbein, Carbon monoxide signals via inhibition of cytochrome $c$ oxidase and generation of mitochondrial reactive oxygen species, FASEB J. 21 (2007) 1099-1106.

[25] S. Balasubramanian, D.G. Lambright, J.H. Simmons, S.J. Gill, S.G. Boxer, Determination of the carbon monoxide binding constants of myoglobin mutants: comparison of kinetic and equilibrium methods, Biochemistry 33 (1994) 8355-8360.

[26] M. Coletta, G. Falcioni, E. Concetti, F. Ascoli, M. Brunori, Liganddependent behavior of the hemoglobin from the ascarid Parascaris equorum, Biochim. Biophys. Acta 870 (1986) 169-175.

[27] M. Coletta, F. Ascoli, M. Brunori, T.G. Traylor, pH dependence of carbon monoxide binding to ferrous horse radish peroxidase, J. Biol. Chem. 261 (1986) 9811-9814.

[28] D.W. Kraus, J.B. Wittenberg, Hemoglobins of the Lucina pectinata/ bacteria symbiosis: I. molecular properties, kinetics and equilibria of reactions with ligands, J. Biol. Chem. 265 (1990) 16043-16053.

[29] G.M. Giacometti, T.G. Traylor, P. Ascenzi, M. Brunori, E. Antonini, Reactivity of ferrous myoglobin at low pH, J. Biol. Chem. 252 (1977) 7447-7448.

[30] T.G. Traylor, L.A. Deardurff, M. Coletta, P. Ascenzi, E. Antonini, M. Brunori, Reactivity of ferrous heme proteins at low $\mathrm{pH}$, J. Biol. Chem. 258 (1983) 12147-12148.

[31] M. Coletta, P. Ascenzi, T.G. Traylor, M. Brunori, Kinetics of carbon monoxide binding to monomeric hemoproteins: role of the proximal histidine, J. Biol. Chem. 260 (1985) 4151-4155.

[32] M. Coletta, P. Ascenzi, M. Brunori, Kinetic evidence for a role of heme geometry on the modulation of carbon monoxide reactivity in human hemoglobin, J. Biol. Chem. 263 (1988) 18286-18289.
[33] M. Coletta, A. Boffi, P. Ascenzi, M. Brunori, E. Chiancone, A novel mechanism of heme-heme interaction in the homodimeric hemoglobin from Scapharca inaequivalvis as manifested upon cleavage of the proximal $\mathrm{Fe}-\mathrm{N} \varepsilon$ bond at low pH, J. Biol. Chem. 265 (1990) 4828-4830.

[34] M. Coletta, P. Ascenzi, R. D’Avino, G. di Prisco, Proton-linked subunit kinetic heterogeneity for carbon monoxide binding to hemoglobin from Chelidonichthys kumu, J. Biol. Chem. 271 (1996) 29859-29864.

[35] E. Antonini, M. Brunori, A. Rossi Fanelli, Studies on the oxidationreduction potentials of heme proteins. IV. The kinetics of oxidation of hemoglobin and myoglobin by ferricyanide, Biochemistry 4 (1965) $545-551$.

[36] J.V. Bannister, W.H. Bannister, P. Ascenzi, A. Focesi, M. Brunori, Oxygen and carbon monoxide binding to myoglobin from the dolphin fish Coryphaena hippurus, FEBS Lett. 65 (1976) 361-364.

[37] S. Goldstein, J. Lind, G. Merényi, Chemistry of peroxynitrites and peroxynitrates, Chem. Rev. 105 (2005) 2457-2470.

[38] M. Exner, S. Herold, Kinetic and mechanistic studies of the peroxynitrite-mediated oxidation of oxymyoglobin and oxyhemoglobin, Chem. Res. Toxicol. 13 (2000) 287-293.

[39] S. Herold, F. Boccini, NO* release from $\mathrm{MbFe}(\mathrm{II}) \mathrm{NO}$ and $\mathrm{HbFe}(\mathrm{II})-$ NO after oxidation by peroxynitrite, Inorg. Chem. 45 (2006) 6933-6943.

[40] D.S. Bohle, P.A. Glassbrenner, B. Hansert, Syntheses of pure tetramethylammonium peroxynitrite, Methods Enzymol. 269 (1996) $302-311$.

[41] W.H. Koppenol, R. Kissner, J.S. Beckman, Syntheses of peroxynitrite: to go with the flow or on solid grounds? Methods Enzymol. 269 (1996) 296-302.

[42] S. Herold, M. Exner, F. Boccini, The mechanism of the peroxynitrite-mediated oxidation of myoglobin in the absence and presence of carbon dioxide, Chem. Res. Toxicol. 16 (2003) $390-402$. 